\title{
Synthesis and characterization of site-selective orbitide- BSA conjugate to produce antibodies
}

Pramodkumar D. Jadhav, ${ }^{\dagger}$ Youn Young Shim,,${ }^{, \dagger}$ and Martin J. T. Reaney, ${ }^{, \dagger *}$

Supporting Information

Supplemental tables:

Table S1. ESI data of BSA

Table S2. ESI data of 11 conjugate

Table S3. ESI data of 15 conjugate

Supplemental Figures:

Figure S1. Synthetic scheme of 9 (A) and 13 (B). Reagents and conditions: a) $\mathrm{NaBH}_{4}, \mathrm{I}_{2}, \mathrm{THF}, \mathrm{RT}$; g) $\mathrm{ICH}_{2} \mathrm{COOEt}$, DIPEA, NMP, $10{ }^{\circ} \mathrm{C}$; h) mCPBA, DCM, room temperature. Taken from Jadhav et al. (2015) $)^{33}$ with permission.

Figure S2. HPLC Chromatograms of 10 (A) and 14 (B).

Figure S3. CID MS/MS spectra of 10 (A) and 14 (B) showing fragmentation pattern.

Figure S4. ${ }^{1} \mathrm{H}$ NMR of 10

Figure S5. ${ }^{1} \mathrm{H}$ NMR of 14

Figure S6. ${ }^{1} \mathrm{H}-{ }^{1} \mathrm{H}$ COSY spectrum of 10

Figure S7. ${ }^{1} \mathrm{H}-{ }^{1} \mathrm{H}$ COSY spectrum of 14

Figure S8. ${ }^{1} \mathrm{H}-{ }^{13} \mathrm{C}$ HMQC spectrum of 10

Figure S9. ${ }^{1} \mathrm{H}-{ }^{13} \mathrm{C}$ HMQC spectrum of 14

Figure S10. ${ }^{1} \mathrm{H}-{ }^{1} \mathrm{H}$ NOESY spectrum of 10 
Figure S11. ${ }^{1} \mathrm{H}-{ }^{1} \mathrm{H}$ NOESY spectrum of 14

Figure S12. ${ }^{1} \mathrm{H}-{ }^{13} \mathrm{C}$ HMBC spectrum of 10

Figure S13. ${ }^{1} \mathrm{H}-{ }^{13} \mathrm{C}$ HMBC spectrum of 14

Figure S14. ${ }^{13} \mathrm{C}$ NMR of 14

Figure S15. ${ }^{13} \mathrm{C}$ NMR of 10

Figure S16. Scheme for NCI-ELISA to detect specific antibodies. $\mathrm{Ag}=$ antigen; $\mathrm{Ab}=\operatorname{antibody} ; \mathrm{E}=$ enzyme.

Figure S17. Recovery of serum immunoglobulins a $3 \mathrm{~mL}$ T-Gel adsorbent column. $1 \mathrm{~mL}$ of anti-1c serum was applied to and recovered from the column using the standard protocol.

Figure S18. Recovery of refined anti-1c serum from a Sephadex G-25 $(15 \times 170 \mathrm{~mm})$ column. 
Table S1. ESI Data of BSA

$\begin{array}{cccc}\text { component } & \text { molecular mass } & \text { absolute abundance } & \text { relative abundance } \\ 1 & 66432.1 & 179833 & 100.00 \\ 2 & 66551.6 & 120662 & 67.10\end{array}$


Table S2. ESI Data of 11 Conjugate

$\begin{array}{cccc}\text { component } & \text { molecular mass } & \text { absolute abundance } & \text { relative abundance } \\ 1 & 93591.9 & 2986 & 100.00 \\ 2 & 81290.4 & 2495 & 83.56 \\ 3 & 84522.5 & 2438 & 81.65 \\ 4 & 84637.2 & 2424 & 81.18 \\ 5 & 51376.1 & 2377 & 79.60 \\ 6 & 84598.2 & 2350 & 78.70 \\ 7 & 57392.9 & 2272 & 76.09 \\ 8 & 81485.6 & 2111 & 70.70 \\ 9 & 30204.6 & 1720 & 57.60 \\ 10 & 81462.4 & 1684 & 56.40\end{array}$


Table S3. ESI Data of 15 Conjugate

$\begin{array}{cccc}\text { component } & \text { molecular mass } & \text { absolute abundance } & \text { relative abundance } \\ 1 & 93612.7 & 752 & 100.00 \\ 2 & 66746.4 & 675 & 89.76 \\ 3 & 31973.1 & 632 & 84.04 \\ 4 & 44139.8 & 618 & 82.18 \\ 5 & 63466.7 & 603 & 80.19 \\ 6 & 90085.1 & 603 & 80.19 \\ 7 & 76398.7 & 590 & 78.46 \\ 8 & 35926.2 & 579 & 76.99 \\ 9 & 41007.5 & 579 & 76.99 \\ 10 & 38453.3 & 568 & 75.53\end{array}$



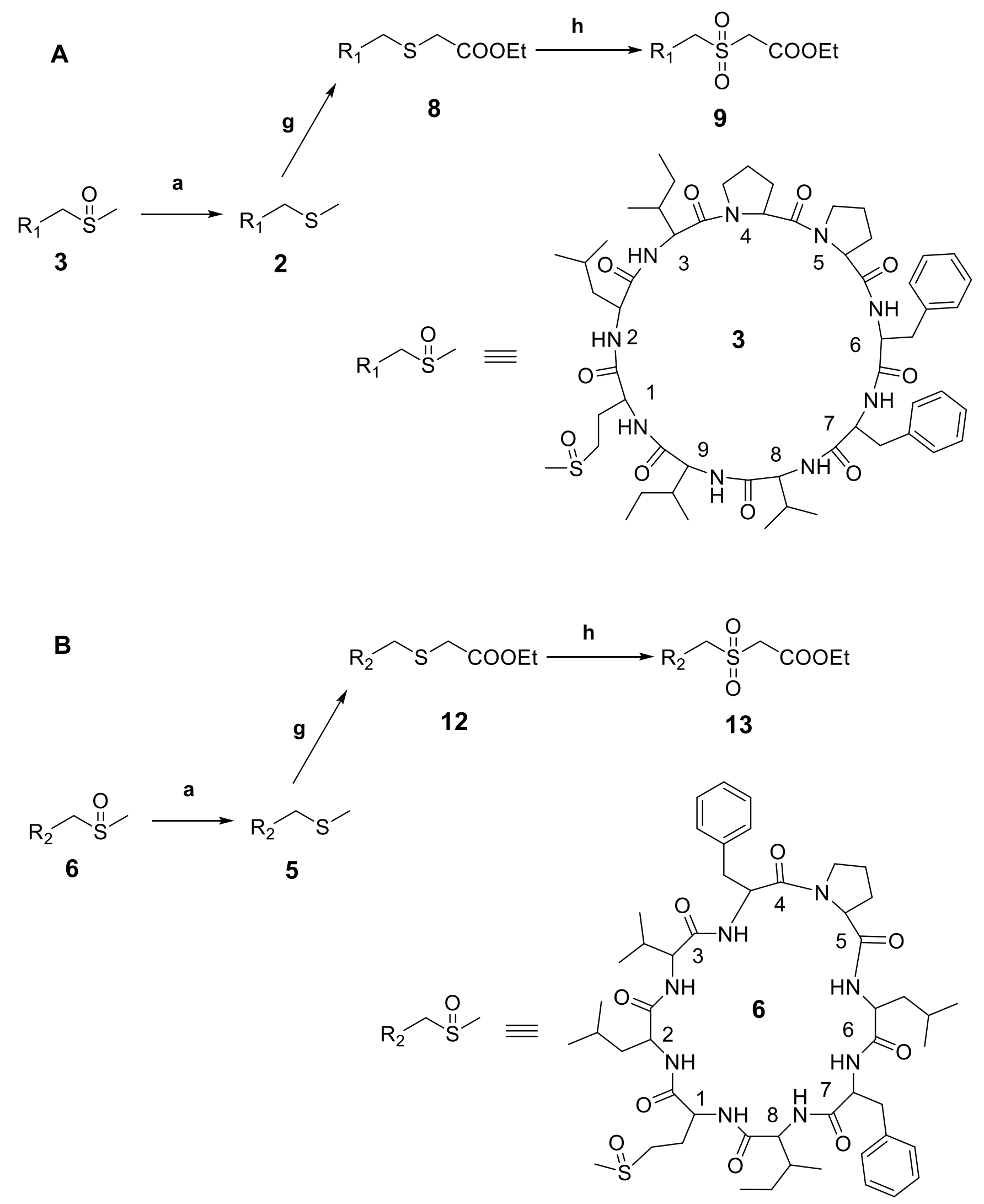

Figure S1. 
A

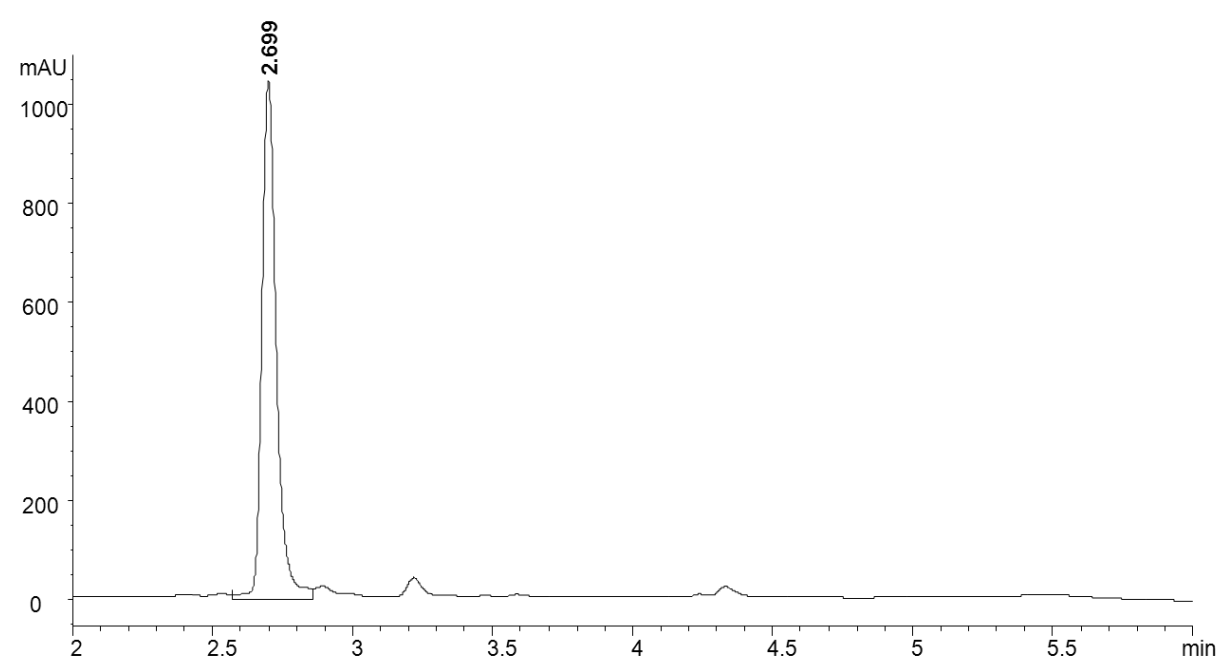

B

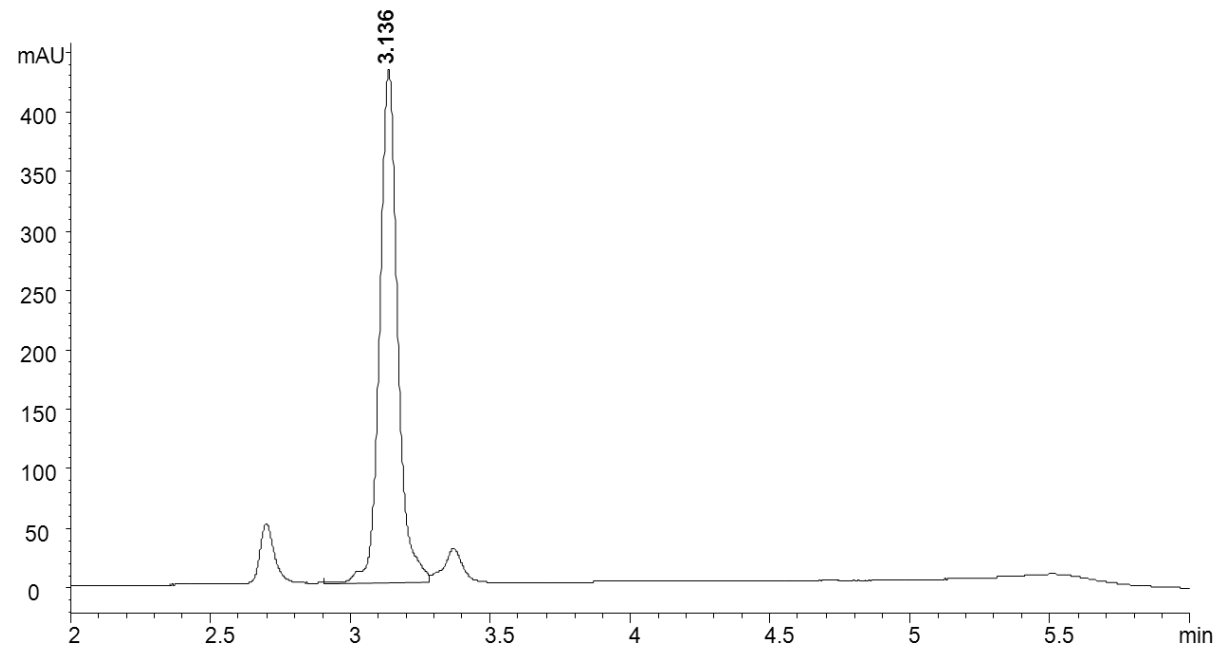

Figure S2. 
A

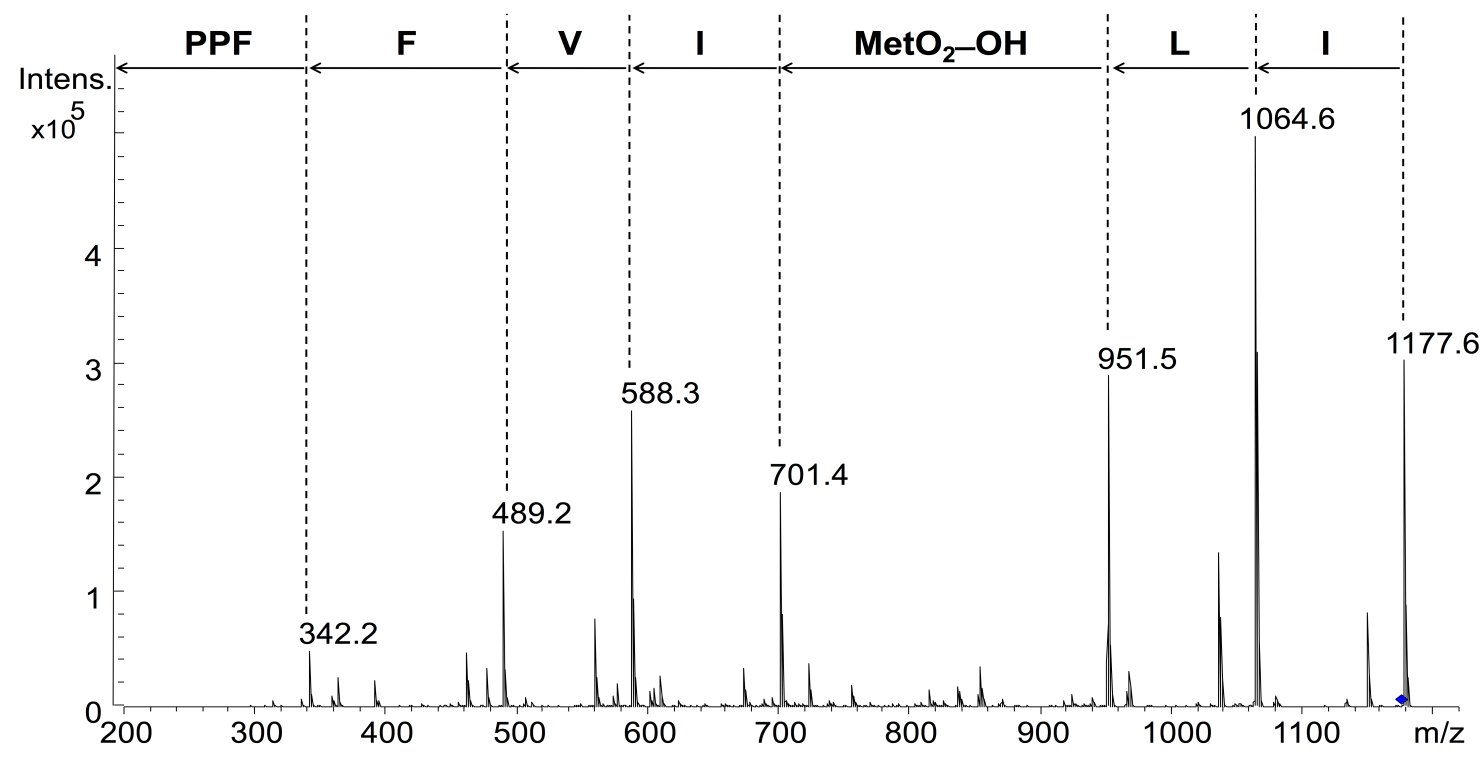

B

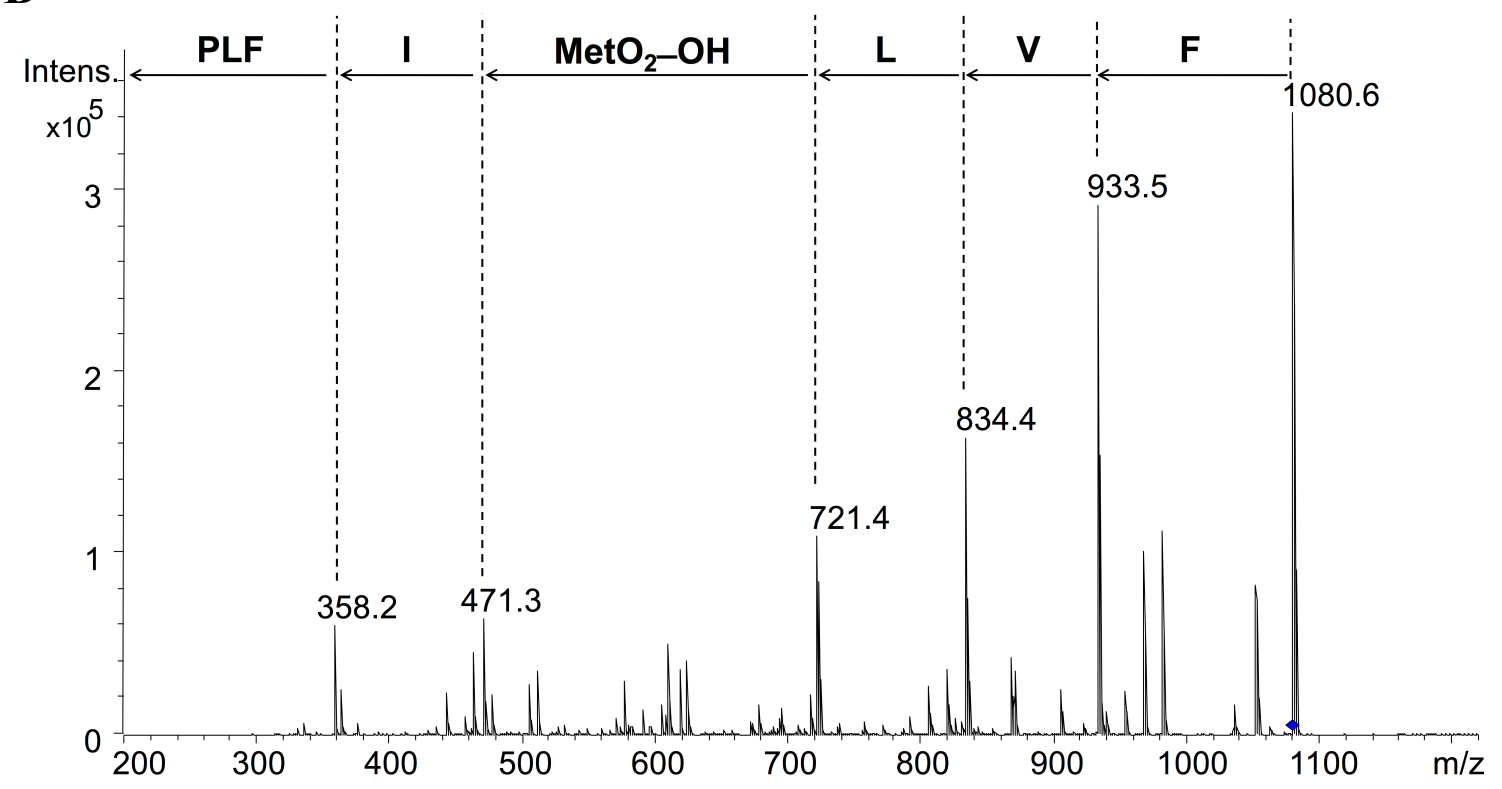

Figure S3. 


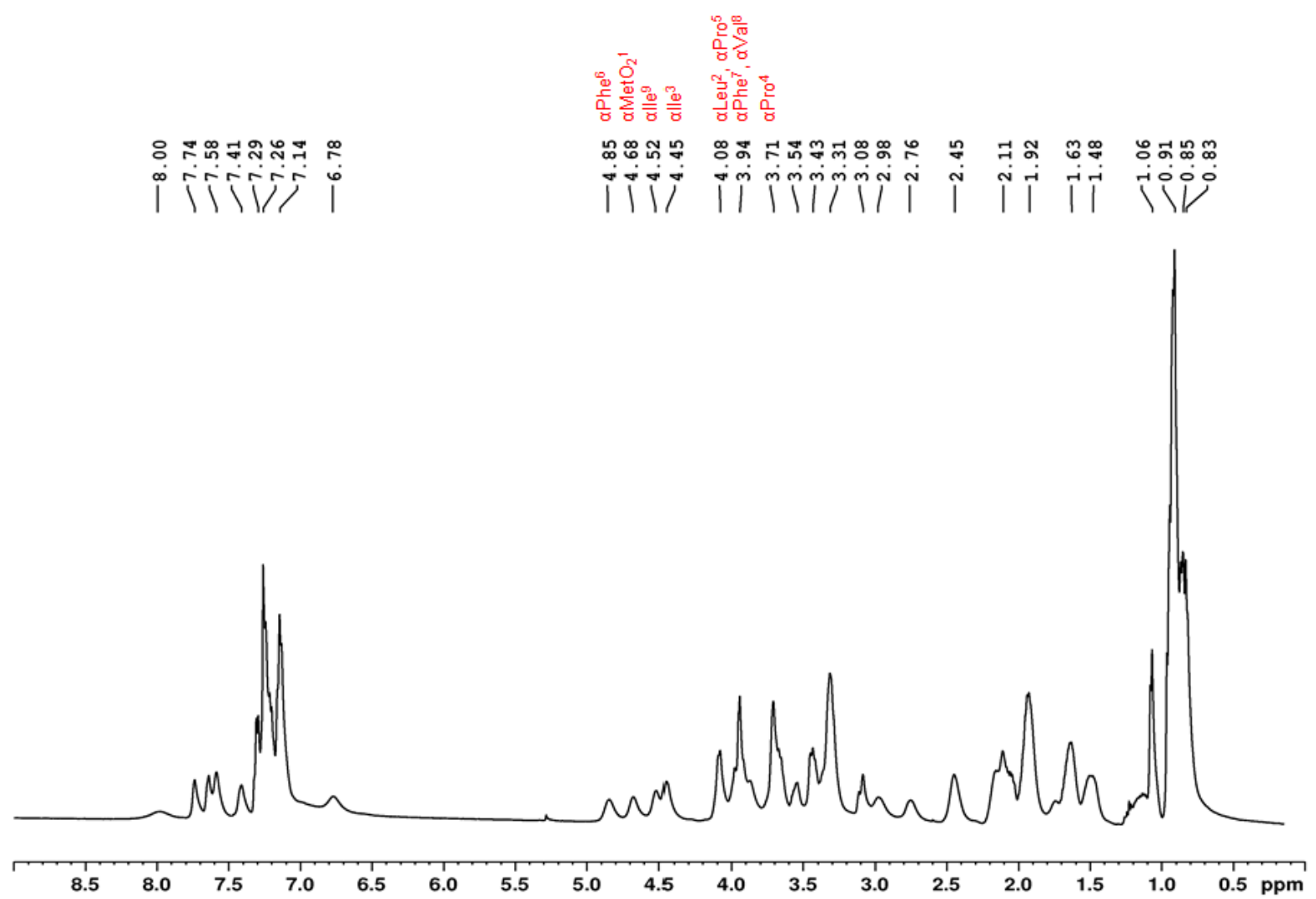

Figure S4. 


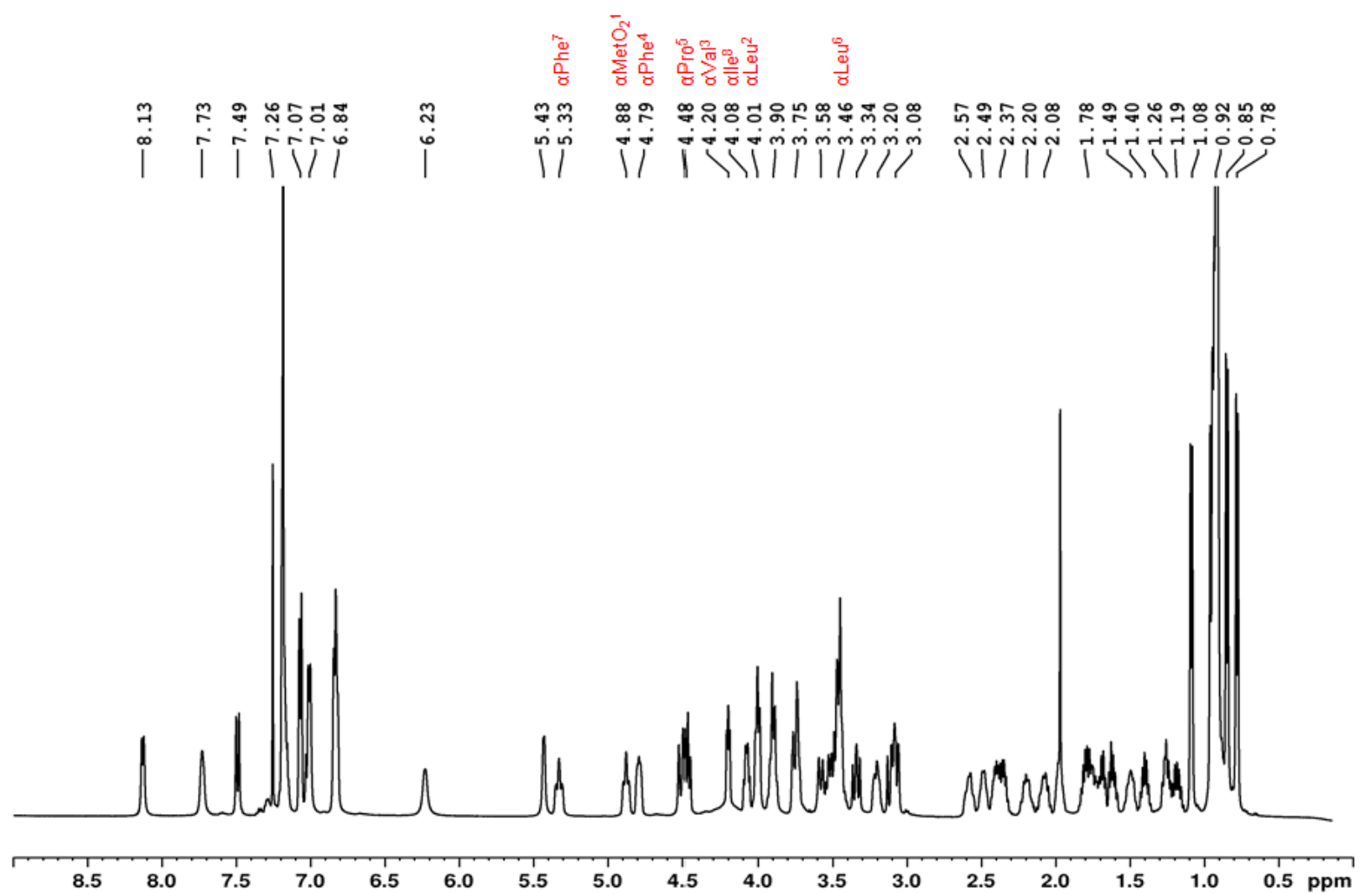

Figure S5. 


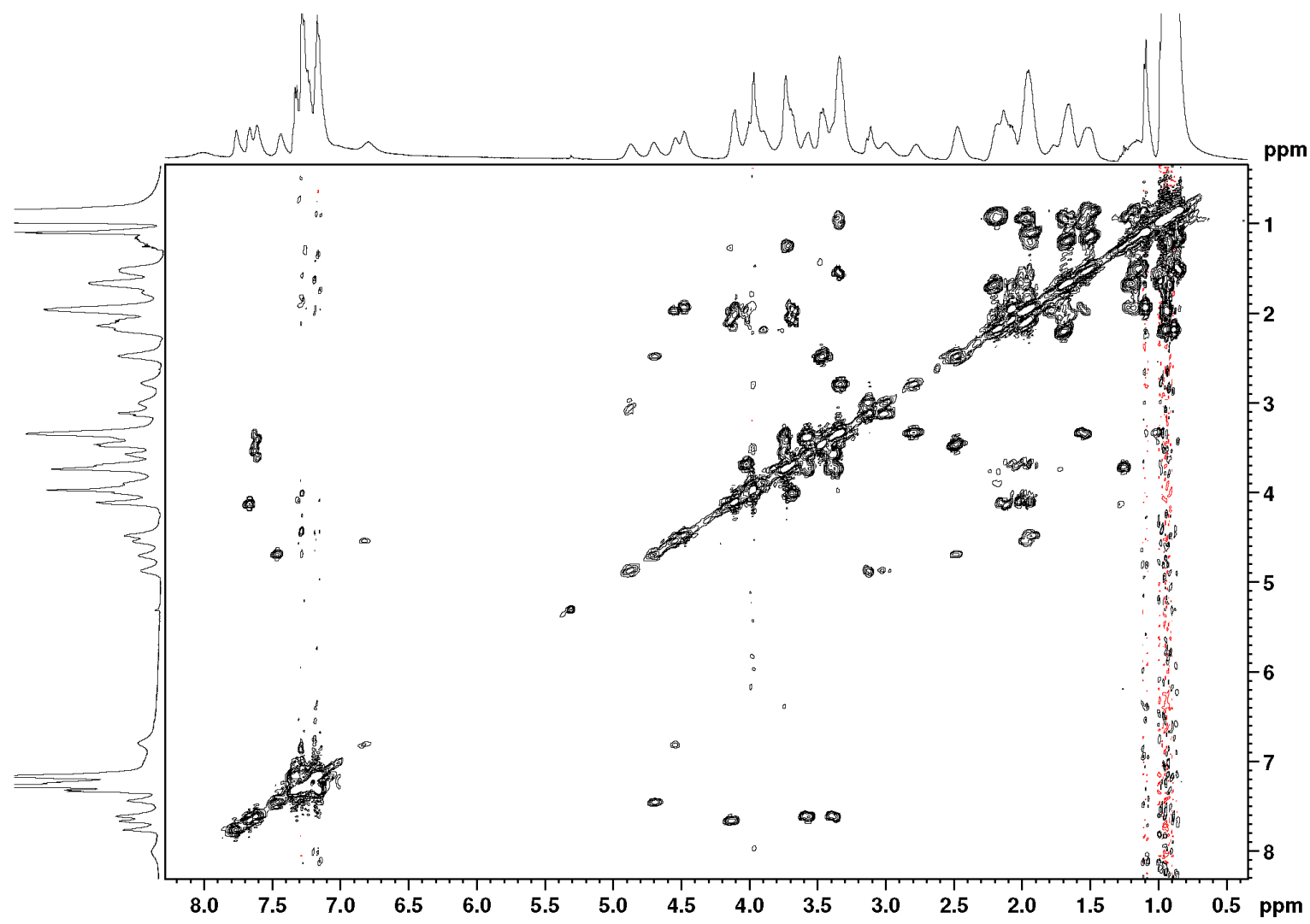

Figure S6. 


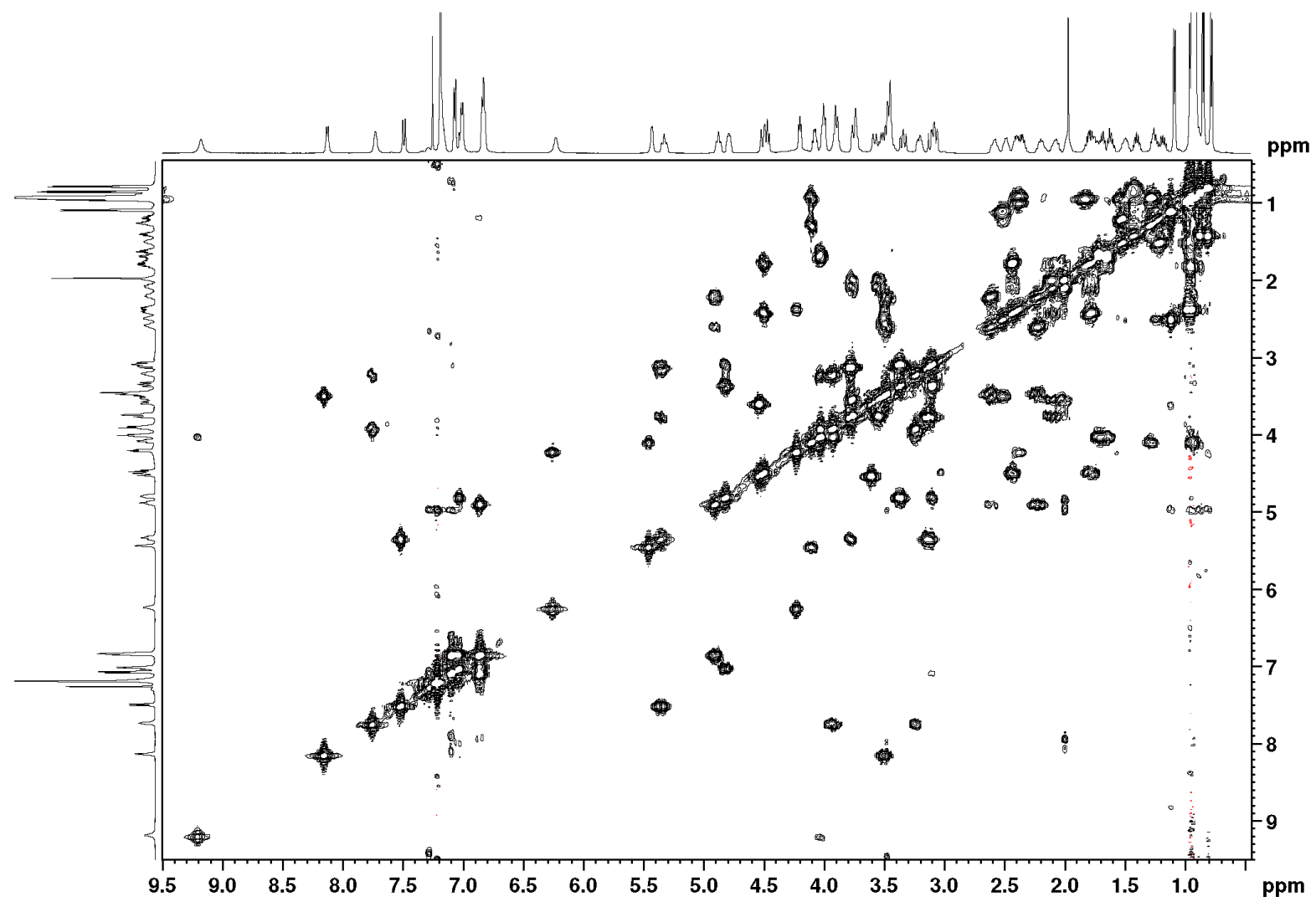

Figure S7. 


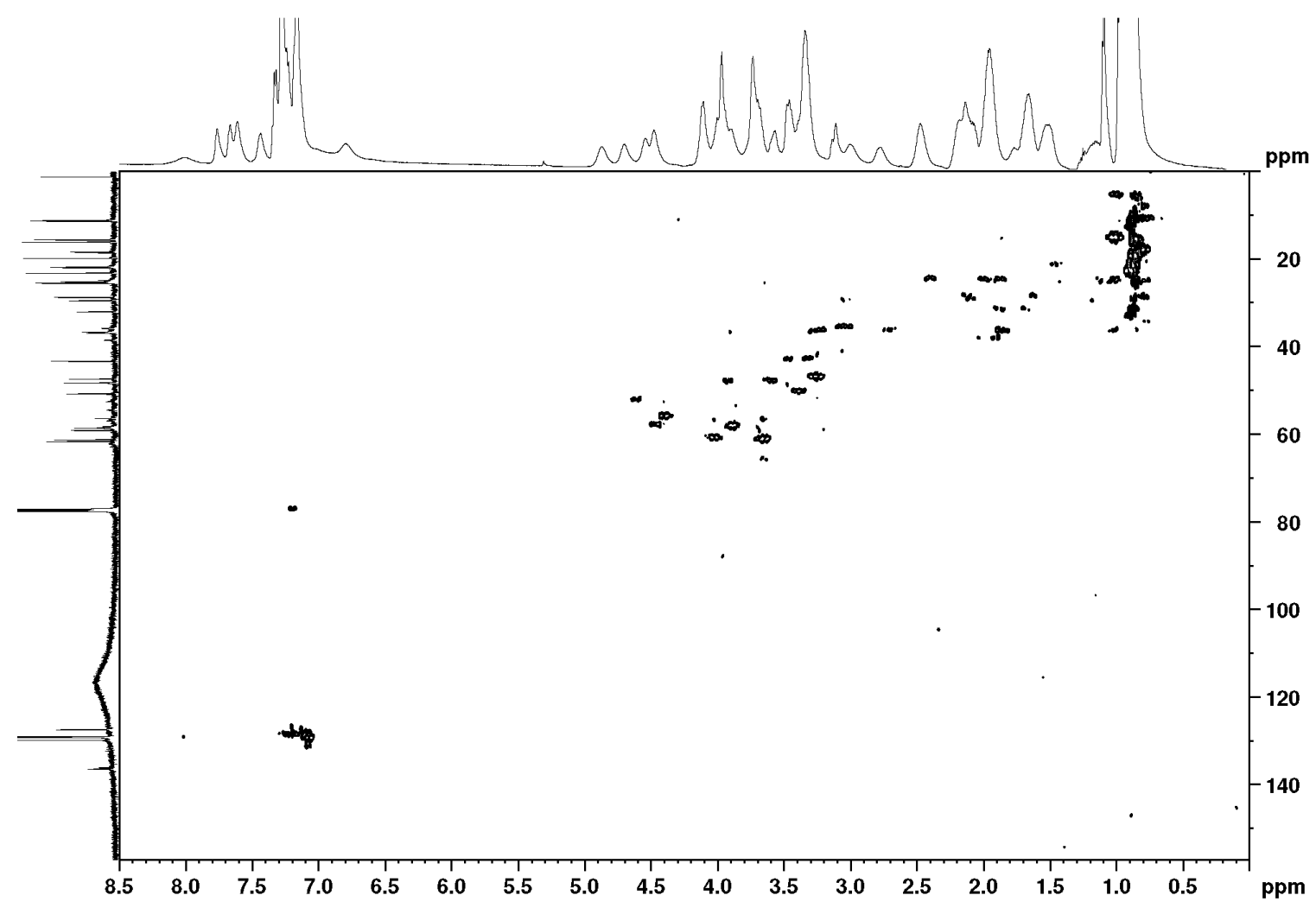

Figure S8. 


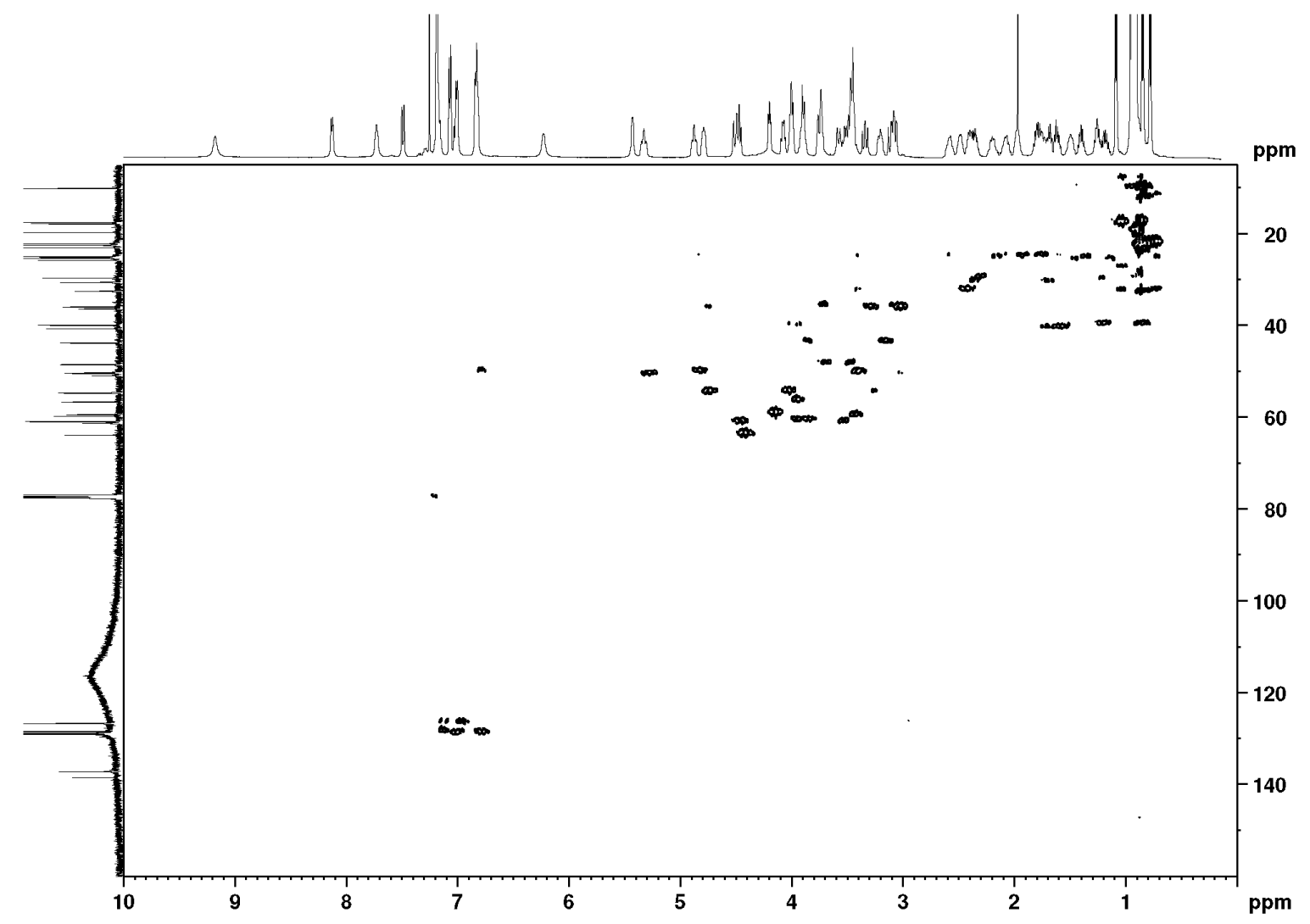

Figure S9. 


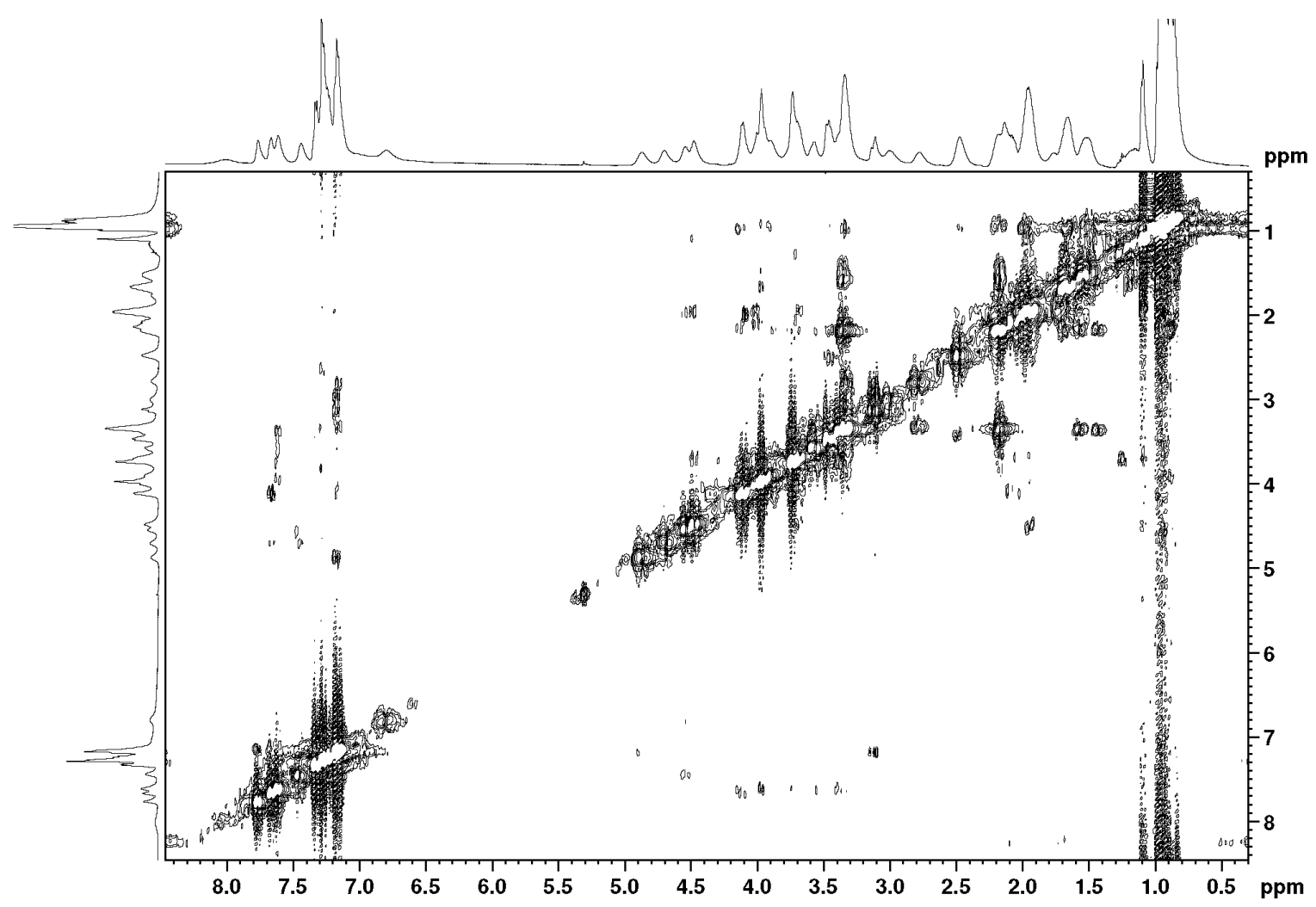

Figure S10. 


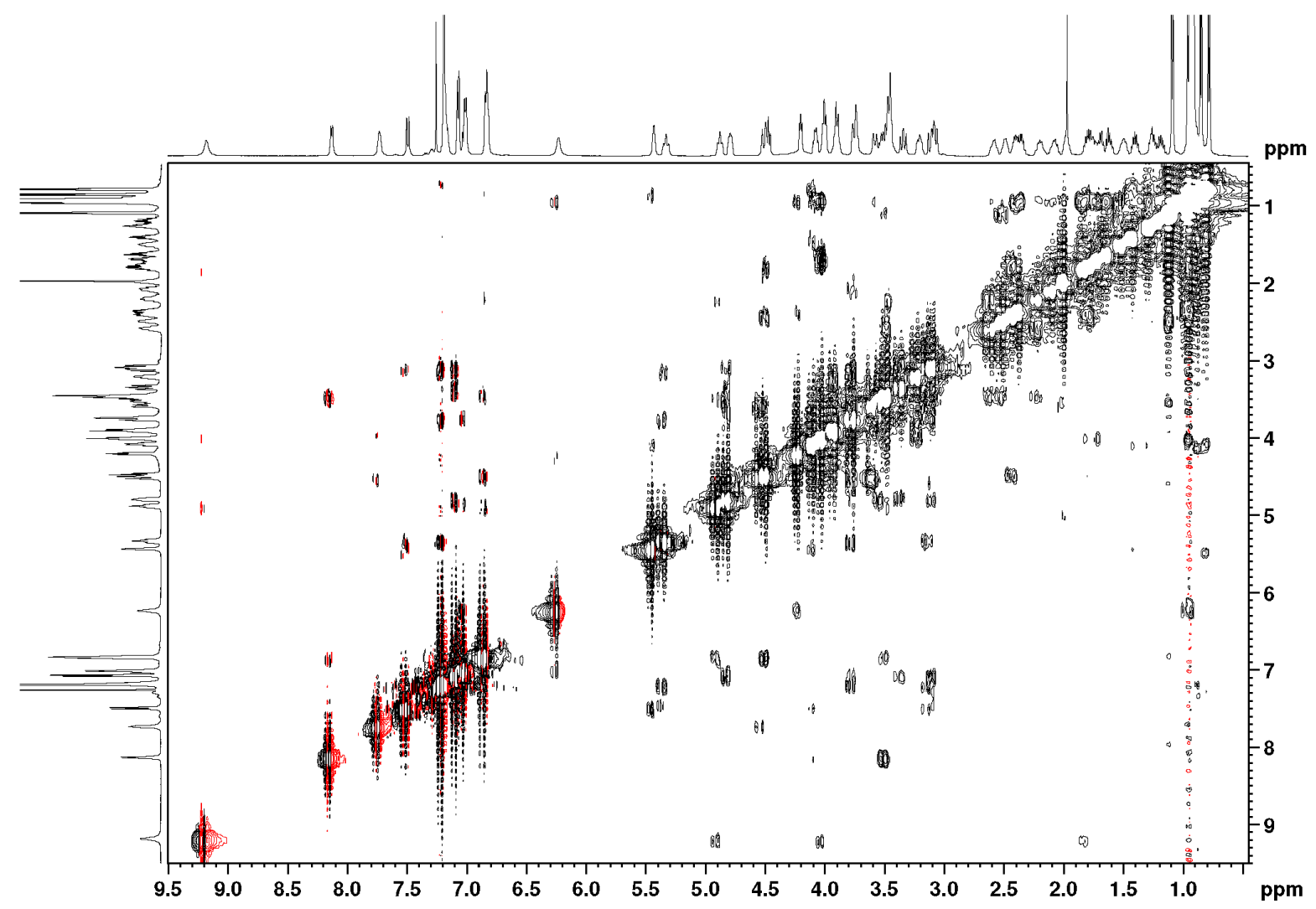

Figure S11. 


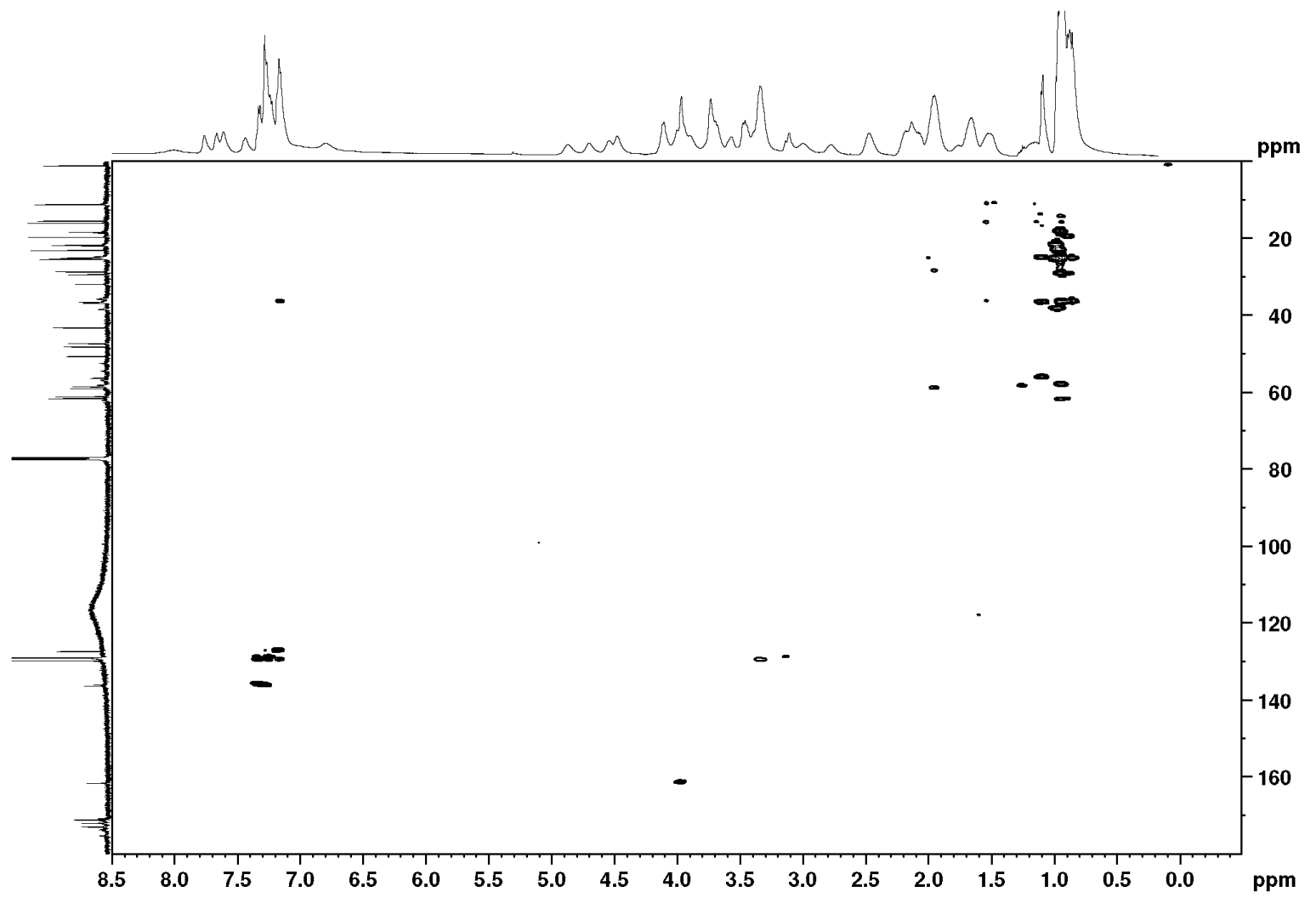

Figure S12. 


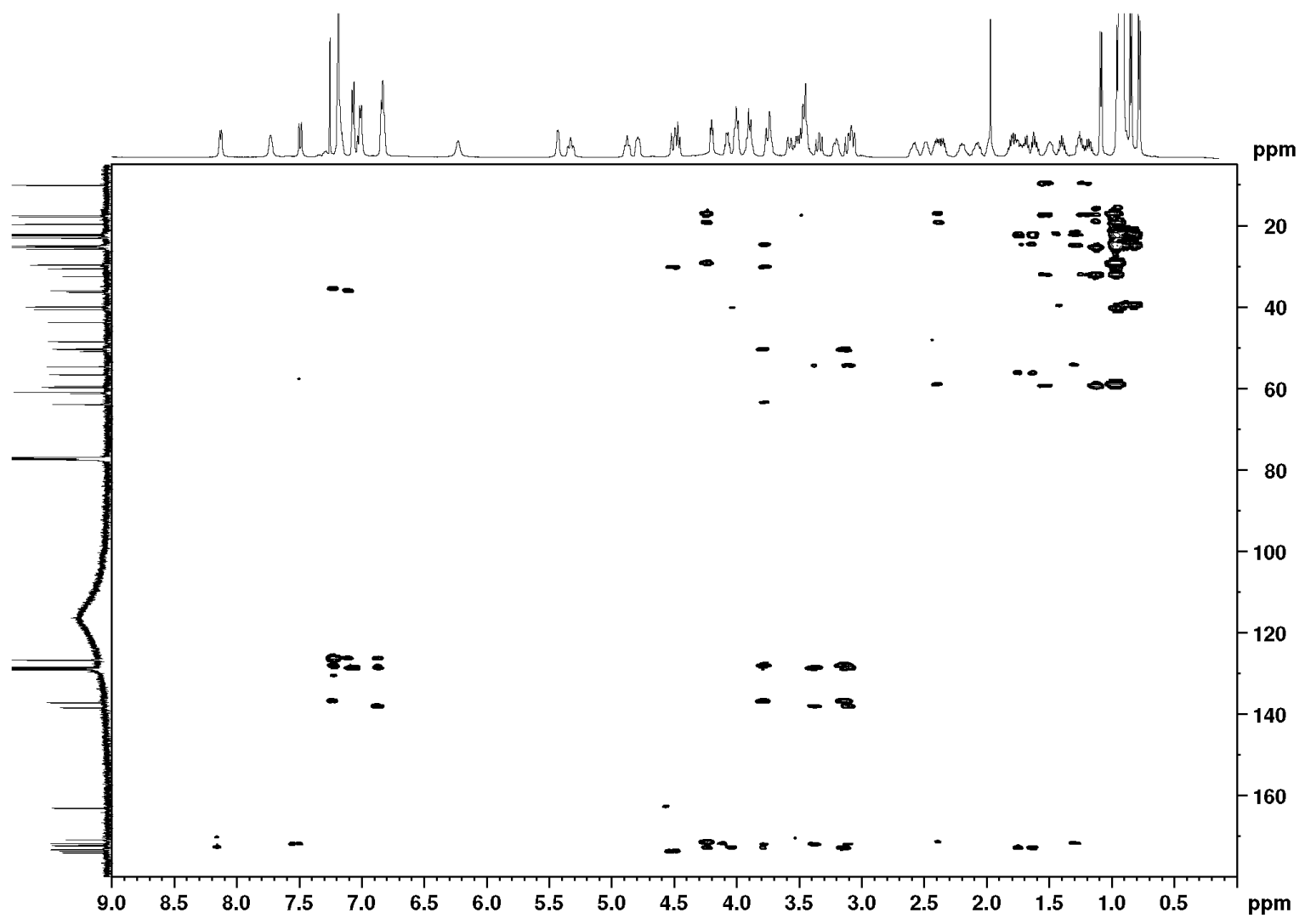

Figure S13. 


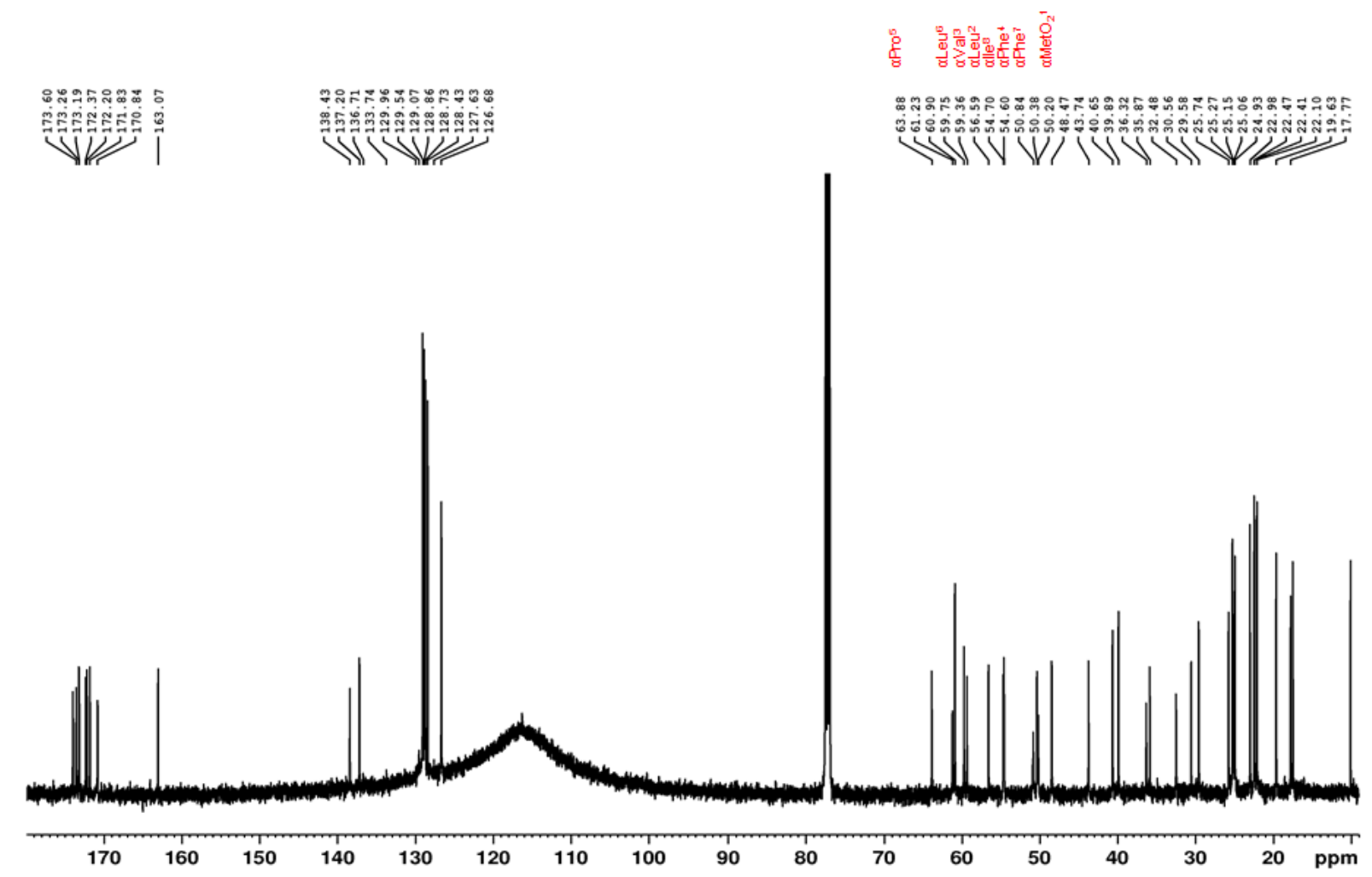

Figure S14. 


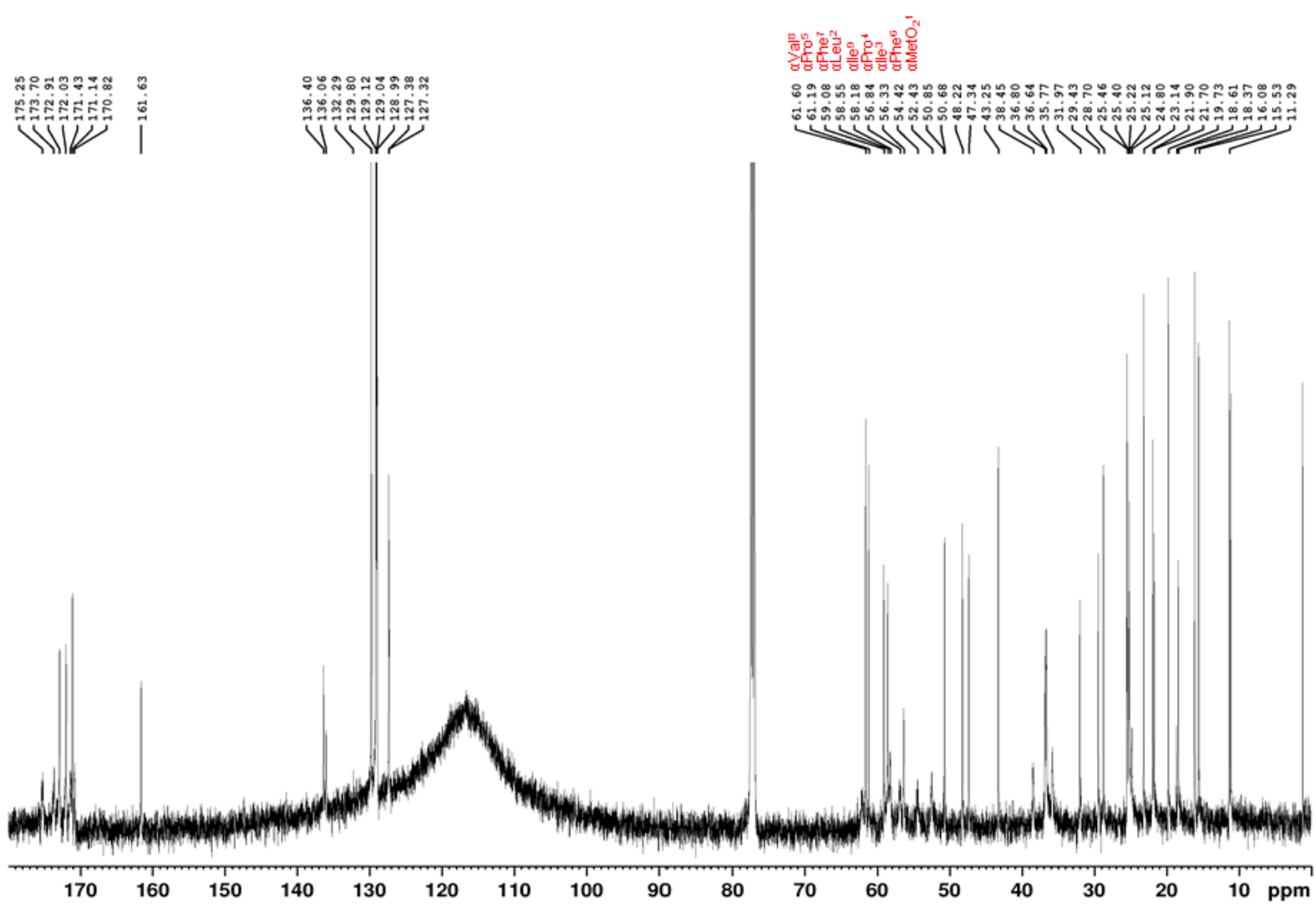

Figure S15. 


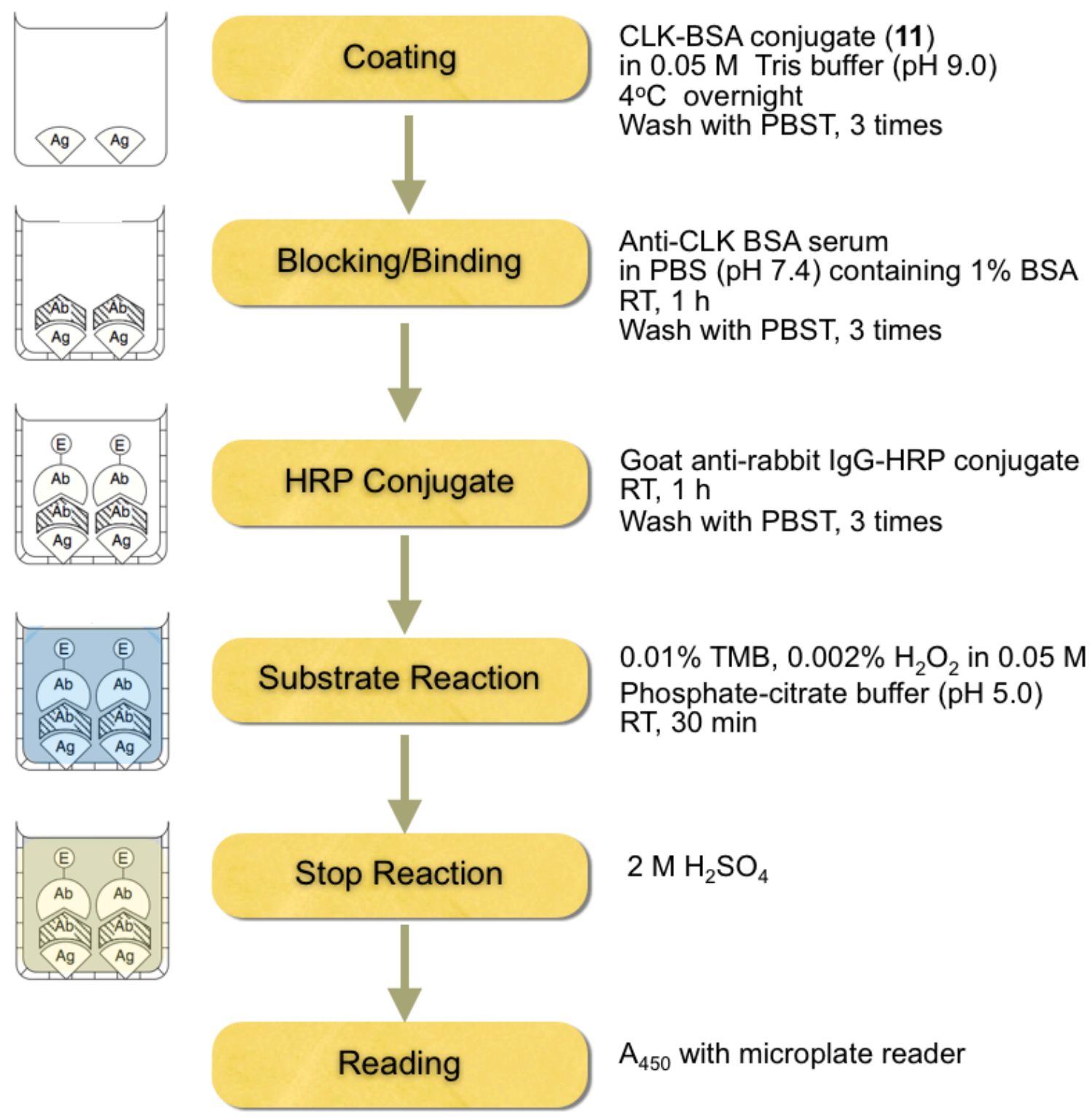

Figure S16. 


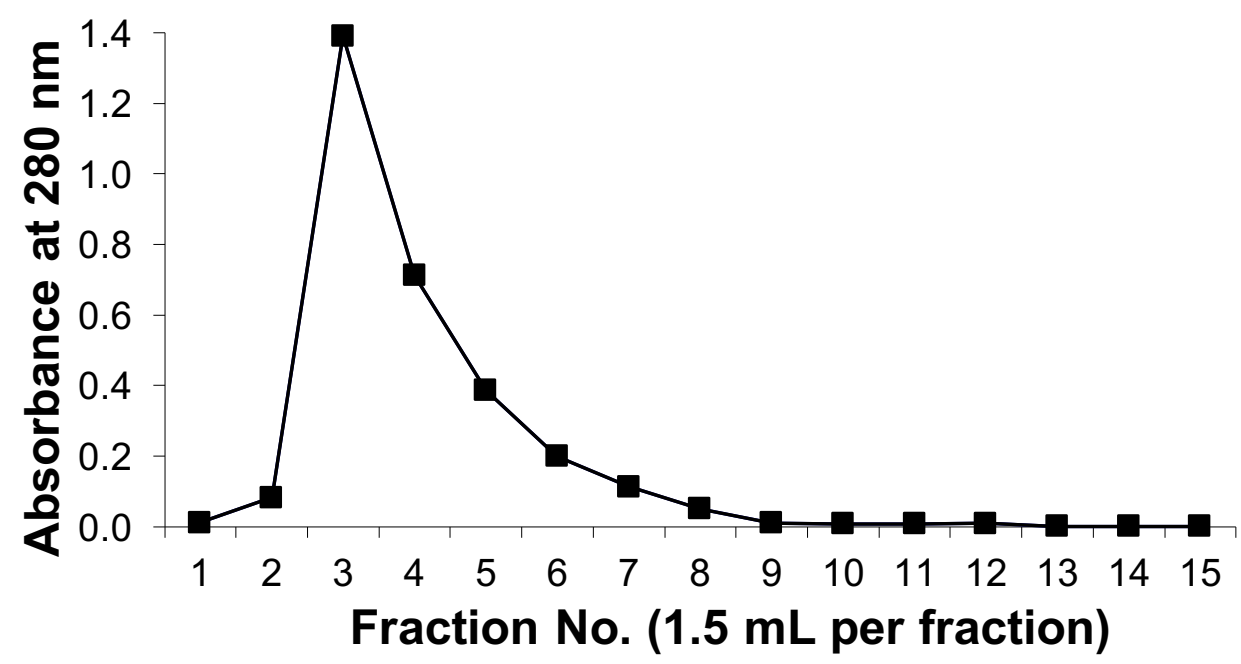

Figure S17. 


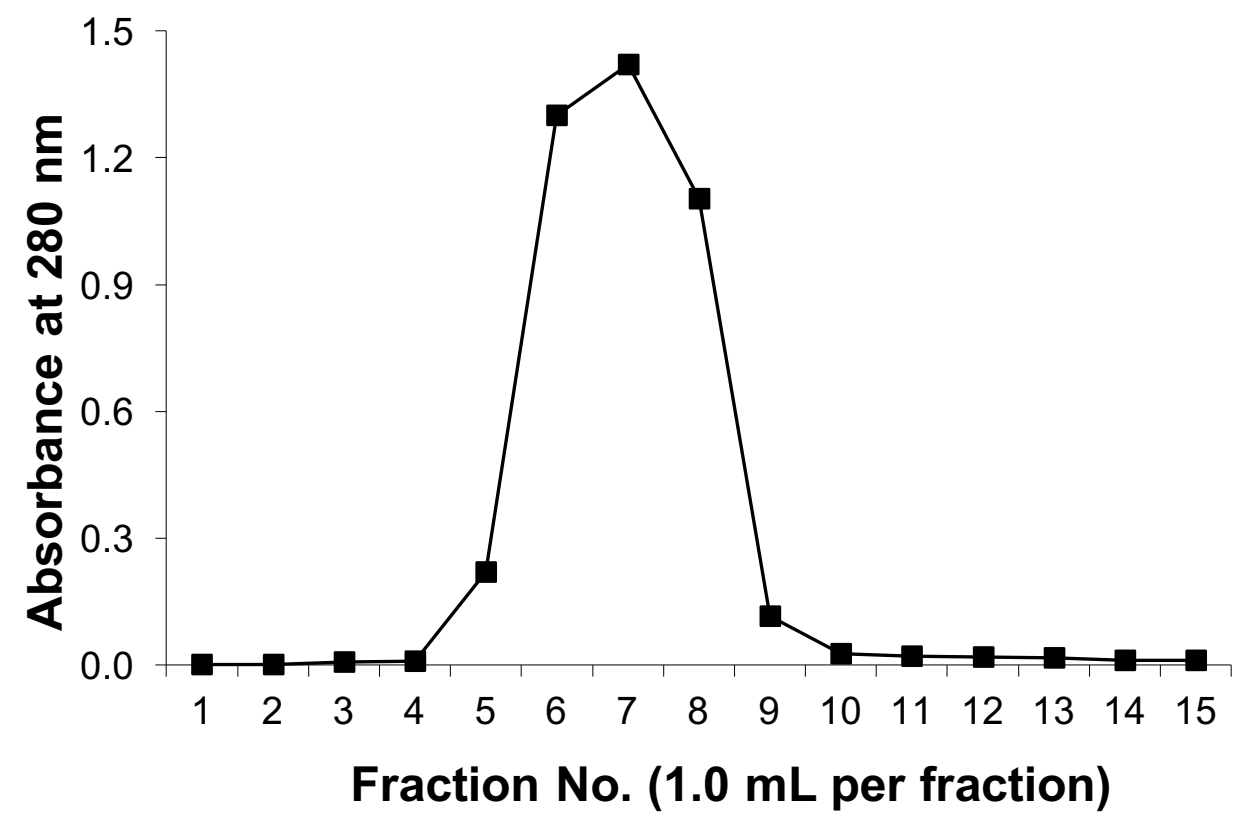

Figure S18. 